\title{
Civic Education Textbook Presentation of Seventh Grade Based on Cultural Literacy and Citizenship
}

\author{
Ismi Sujastika ${ }^{1, *}$, Aim Abdulkarim² \\ ${ }^{1,2}$ Universitas Pendidikan Indonesia, Bandung, Indonesia \\ *Corresponding author.Email: ismi.ch17@upi.edu
}

\begin{abstract}
The purpose of this study was to develop a civic education textbook presentation of seventh grade Based on Cultural Literacy and Citizenship. The background of this research is the importance of cultural and civic literacy skills that must be possessed by students. Cultural literacy and citizenship are some of the six basic literacies that must be possessed in the era of the industrial revolution 4.0. To realize the ability of cultural literacy and citizenship, what must be done is to understand, interpret, believe and practice the values of law, politics, and national culture. Textbooks are one of the learning resources used by students directly in learning activities. The function of the textbook is very supportive of the learning process or improves students' understanding of the subject matter. Therefore, the presentation of textbooks, especially Civics Education textbooks, must support the mastery of these literacy skills. The method used in this research is the R\&D development method with the ADDIE model. The results showed that civic education textbook presentation of seventh grade Based on Cultural Literacy and Citizenship should be emphasizing three aspects of learning, namely: 1. Presentation of Material Content, 2. Design of Learning Models to be used, 2. Assignment form to be given. This study concludes that the presentation of material in the Civics Education textbook for Class VII SMP based on Cultural Literacy and Citizenship is very helpful for students in understanding the culture of the Indonesian nation, and preparing themselves for the era of the industrial revolution 4.0.
\end{abstract}

Keywords: Citizenship, Cultural Literacy, Textbook Presentation.

\section{INTRODUCTION}

121st-century learning is designed by integrating various abilities to students, including the integration of attitudes, skills, knowledge, mastery of technology, and literacy skills. Literacy skills are additional skills that must be mastered by students in the 21 st century, including because the need for reading skills today will be very helpful in mastering technology. There are at least six types of literacy that students must have in the 21 st century, namely reading and writing literacy, numeracy literacy, scientific literacy, digital literacy, financial literacy, and cultural and civic literacy. The importance of 21 st-century skills makes the government seriously discuss these interests in a curriculum, namely the 2013 curriculum. This curriculum change automatically changes various cultures or habits in education. Learning is no longer measured from the area of affective knowledge alone. However, a balance of judgment applies. Learning objectives in the curriculum are focused on basic competencies. These basic competencies are a source of reference in determining indicators of achievement of learning competencies. To achieve learning competence, learning media is needed that can convey our goals easily. Among them, books are used as a source of learning.

The textbooks used today are subject textbooks that are adapted to the current curriculum. Therefore, the presentation of a textbook is certainly considered to meet several criteria for presenting a textbook. The ideal textbook that is following the 2013 curriculum must at least meet the assessment standards made in the 2013 curriculum, including the 2013 curriculum, including (1) containing material with balanced competence aspects, both cognitive, affective, and psychomotor, (2) encouraging the learning process. learning with a scientific approach, and (3) encouraging the assessment of learning outcomes to be carried out authentically. [1]

Cultural literacy and citizenship became one of the six basic literacies launched by the World Economic Forum in 2015. The six basic literacies are numeracy 
literacy, scientific literacy, literacy, financial literacy, digital literacy, and cultural and civic literacy. Cultural literacy is one of the important points of literacy skills that must be possessed in the 21st century. Data from the Ministry of Education and Culture shows that in 2015 the number of illiterates in Indonesia reached $3.56 \%$ of the 5.7 million people spread throughout Indonesia. This fact is a major blow for us, especially considering the reality of the increasingly fierce competition in life in the 21st century.

The survey conducted by the Program for National StudentAssesment (PISA) conducted in 2018 known that the ability to read people in Indonesia was ranked 74th out of 79 participants of the survey [2]. Literacy skills include the ability to process information from the data and interpret the readings in a particular context [3]. Low test results are of course makes us concerned about the ability to survive for prospective young people in the days to come. Especially in the face of challenges from within and from outside.

The challenge from within is the multicultural condition of the Indonesian nation. If this condition is not addressed with a good understanding, the ability to understand the situation and think broadly, it will certainly cause a lot of problems. Therefore, cultural and civic literacy became one of the literacy skills that must be possessed by students.

\section{THEORETICAL REVIEW}

\subsection{Cultural Literacy and Citizenship}

Aprinta [4] describes that cultural literacy is a person's knowledge of the history, contributions, and perspectives of different cultures that are used in reading and writing activities. In simple terms, it can be understood that cultural literacy is the ability to read deeply about culture and implement it in the form of activities and writing. Hirsch in Hermawati [5] suggests that the development of cultural literacy occurs because of the process of studying other people's cultures through reading and writing activities.

Culture is formed in various dimensions of life. In the simplest form, namely the family, culture occupies an important role in the distinctiveness that binds them. For example, the family's values will be different from other families. In a broader context, namely the life of the nation, culture binds agreed inter-personal relationships is characteristic along which we know as the national culture, global cultures, and various other values.

Cultural literacy exists as a form of anticipation of the negative things that arise as a result of globalization. Cultural preservation must be done by communicating culture using appropriate media. In schools, textbooks are one of the learning media used to fill the horizons of students' understanding.
Suryadi [6] defines civic literacy as the knowledge and ability of citizens to find solutions to life's problems. Citizenship literacy here is interpreted as a basic element of civics knowledge that is manifested in civic activities. The importance of civic literacy for students is that students know their rights and obligations as citizens. This is also stated by Hadiansyah, et. al [7] that civic literacy is knowledge and skills in understanding the rights and obligations of citizens.

In general, cultural literacy and citizenship can be interpreted as a person's ability to understand a particular culture. This is in line with the definition of cultural literacy and citizenship in the book supporting material for cultural literacy and citizenship [7] is the ability to act and make decisions as part of a culture and nation towards its social environment.

\subsection{PPKn Textbook}

According to Mohammad Numan Somantri in Abdul Aziz Wahab [8] Citizenship Education is the selection and adaptation of cross-disciplinary social sciences, civics, humanities, and basic human activities that are organized and presented psychologically and scientifically to participate in achieving one of the goals of education. IPS. Civics as moral education, values education, political education, legal education, and human rights education in schools.

In addition, Azyumardi Azra in Idris Apandi [9] states that civic education is education that has a wider scope than democracy education and human rights education, because it includes studies and discussions on many things, such as; governance, constitution, democratic institutions, rule of law, rights and obligations of citizens in civil society, knowledge of institutions and systems in government, politics, public administration and law, knowledge of human rights, active citizenship, and others.

Abdul Aziz Wahab [8] wrote that there are three scopes of Civics, namely; civic knowledge, and civic disposition, and civic skills. Citizenship knowledge is related to equipping students with many knowledge that is the basis for being intelligent, critical, democratic citizens, respecting human rights, obeying the law, knowing political rights and obligations as citizens, knowing the role of state institutions, and so on.

Good presentation of textbooks includes fulfilling several criteria for writing textbooks as proposed by Greeny and Petty, in Tarigan [10], namely; attract readers' interest; able to give spirit to the readers, contain interesting illustrations, consider the linguistic level of the readers, relate to other lessons, be unambiguous in explaining concepts, have a clear and firm point of view, emphasize clear values for children and adults, and be able to appreciate differences for the readers. 
To answer the various challenges and problems that exist, the presentation of the textbook is made in such a way, so that students are interested in continuing to learn. In addition to this, another functions of textbook according to Greene and Petty in Tarigan [10] are as a reflection of the learning system, as a learning medium that motivates students, as supporting tasks and practices in learning, and as presenting a rich subject or subject. easy to read, and varied according to the interests and needs of the student as the basis for the recommended program of activities, expressional skills, which are acquired under real-life-like conditions.

The presentation of the Civics Education textbook should cover all scientific aspects of Civics. There are three domains of Civics knowledge that students must possess, namely Civics knowledge, Civics skills, and citizenship attitudes. These three aspects of Civics learning are the main keys in presenting existing textbooks. In addition, it should also emphasize the elements of cultural literacy and citizenship in it.

In addition to the three scientific aspects of Civics, the presentation of textbooks should also describe three general aspects, namely pedagogy, material, and readability. Lee Shulman in Agustina [11] states that the pedagogical aspect in the textbook is intended so that the reader can respond to the problems in the material presented. In general, the response to something means a new form of knowledge possessed by someone after obtaining information. The pedagogical aspect in textbooks has a central role. Among them are habituation of learning activities, as a learning resource, and as a learning practice guide (Mike Horsley and Richard Walker [12]. Lambert [13] suggests that the pedagogical aspects of textbooks aim to become a learning guide for teachers, as a means of learning motivation, and as a class organization management tool. From the statement above, it can be concluded that the pedagogical aspect in the textbook has a role as a guide for student learning in the classroom, class organizing media, and a tool to motivate student learning.

Hamdi [14] stated that the scope of the material aspect are both of scope and sequence. The organization of the subject matter or subject area is generally explained that the scope relates to the depth and breadth of the material, while the sequence relates to the order of the material based on the learning curriculum. Abdulkarim [15] mentions that the preparation of learning materials consists of expanding the environment, expanding community, and expanding thematically. Ahmad Sanusi [16] wrote that the organization of subject matter must meet the scientific nature of the present (up to date). Textbooks must be able to fulfill the spirit of curiosity, factual, analytical, and creativity in students.

The procedures for presenting the material include writing the formulation of the subject matter, making a concept map that is under the lesson plans, determining the order of presentation, writing the material inductively with the good and correct language, and the last is the inclusion of pictures, diagrams and others that are by material.

Aspects of readability or Readability include the condition of the text visually. Tampubolon [17] writes that the readability of textbooks is related to the suitability of the level of difficulty of reading. Dale and Chale (Oakland and lane, [18] define readability as certain elements of reading or textbooks that affect the understanding of readers. Rusyana [19] says that the aspect of readability in textbooks concerns reading regarding the use of language, its ease of reading, content, style of language, and the suitability of reading and reading in certain circumstances. Furthermore, Gilliland [20] stated that the readability of a text is influenced by three main things, namely the ease of typography, the second is interesting, and the third is providing new understanding.

Presentation of textbooks with a special organization to facilitate the learning process. Mudzakir [21] states that the organization of textbooks has three characteristics, namely: 1) structured in chapters and another Chapter. 2) learning content must be complete, including concerns with information, explanations, comments, practical exercises, summary, and evaluation) are presented regularly; and 3) there is systematic learning progress that leads to the acquisition of new knowledge and learning new concepts based on the items of knowledge already known.

One important thing that cannot be forgotten in the presentation of textbooks is the form of assignments that will be given to students. This assignment must be considered because with this students will be directed to achieve the desired learning goals. In designing assignments for the presentation of a civic education textbook presentation of seventh grade Based on Cultural Literacy and Citizenship have to seeing on the learning objectives made. These learning objectives are usually made based on core competencies (KI) and Basic Competencies (KD) contained in the curriculum.

Presentation of textbooks PPKn based cultural literacy and citizenship must include cultural elements and concepts of citizenship are obvious. Cultural elements that should be included cover the area cultural, national, and international. The element of citizenship that should be included in it is to put the concept of citizenship with clear, detailed, and applicable (National Literacy Movement [8].

\section{METHODS}

This study uses a descriptive qualitative approach which aims to obtain scientific data and facts information. This type of research is research and development, namely research conducted to produce a 
product and test its validity.[22] The development of the textbook used is the ADDIE model. ADDIE stands for Analysis, Design, Develop, implementation, evaluation. This model was first developed by Reiser and Molenda in 1990 [23]. The stages of research with the ADDIE model are carried out sequentially and systematically. So, the entire series of research is carried out in stages but remains in a series of systems. As shown in the image below:

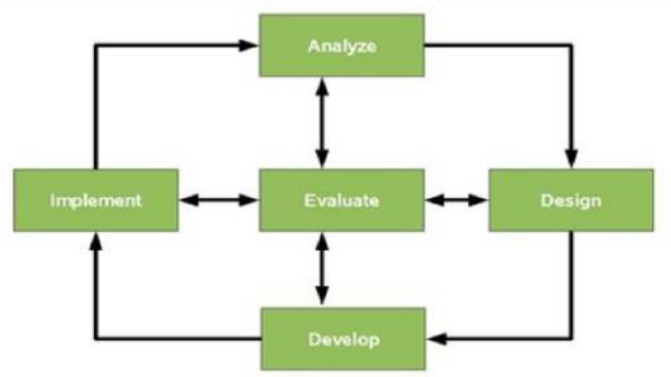

Figure 3.1. ADDIE Development Model

The picture above shows the stages of developing the ADDIE model in development research. The stages of the research as shown in the picture above are:

\section{Analysis}

At this stage of analysis, the researcher conducted a preliminary study and prepared various sources relevant to the presentation of the Class VII Civics Education textbook based on cultural literacy and citizenship.

\section{Design}

At the design stage, the researcher compiles various research media, assessments, and analyzes that will be carried out. Where in general, researchers make research tools.

\section{Develop}

This development stage is carried out by combining all elements of the research. This stage is the most decisive of all the stages that have been planned.

\section{Implementation}

This stage is the stage of implementing the media used in the research class.

\section{Evaluation}

Evaluations are generally carried out to determine the effectiveness of the use of research media that has been developed. There are two types of the evaluation carried out in this study. Namely formative and summative evaluation.

This research was conducted at Islamic Junior High School Azzahra Bandar Lampung. This research was conducted from the beginning to the end of August 2021. The research subjects were grade VII students. Data collection techniques by observation, study documentation.

\section{RESULTS AND DISCUSSION}

This research is development research that aims to obtain learning products. The development model chosen is the ADDIE model. Therefore, the results of the discussion related to the implementation of the application of the research phase with the ADDIE model. The following are the procedural steps made by the researcher in presenting the development of the Class VII Civics Education textbook based on cultural literacy and citizenship.

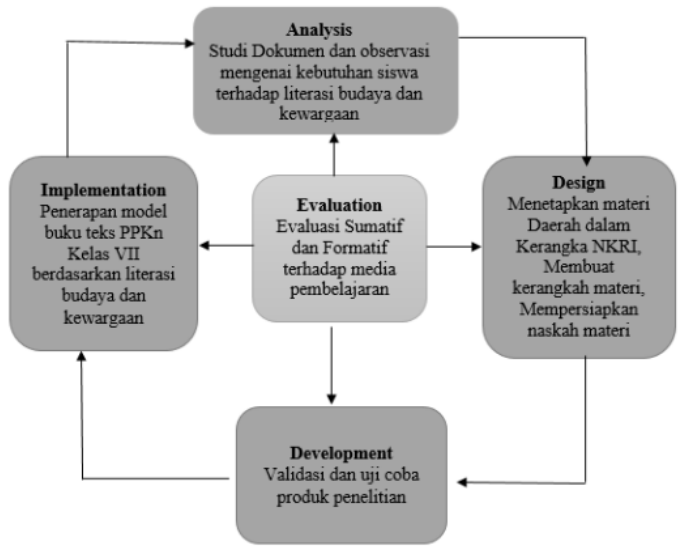

Figure 4.1. Development of the Civics Class VII textbook model based on cultural literacy and citizenship using the ADDIE model

The research begins by conducting an analysis first, where at this stage the researcher makes observations first to determine the students' needs for presenting Civics textbooks based on cultural literacy and citizenship. After making observations in the field, it is known that many students do not understand the origin of culture, cultural values, and the importance of upholding cultural values.

Furthermore, the researchers designed the presentation of the material in the textbook whose contents included the results of the observations that had been made. This design includes the inclusion of textbook presentation elements, namely material, language, presentation, and graphics, Textbook Model Design, and Assignment Forms that will support increasing the ability to understand cultural literacy and citizenship.

The next step is implementation. At this stage, the research design that has been made is then implemented into the research class. Implementation implements done twice. The first is when testing the research product that is made. After being tested in the experimental class, the research product will continue to be revised or improved. After that, it is tested again until students get maximum learning results. 
The final stage is the stage of evaluation. Evaluations were performed at this stage there are two types. The first is a formative evaluation. Formative evaluation is performed at the stages do. In other words, this evaluation is a form of periodic repairs carried out by researchers. The summative evaluation is conducted at the end of the study to determine the final result of the product of research that has been done.

The pedagogical aspect of the seventh-grade Civics Education textbook based on cultural literacy and citizenship means presenting the textbook as a learning guide and media to motivate students to learn by including the values and attitudes that citizens must take in dealing with their social environment. Presentation of textbooks in the pedagogical aspect based on cultural literacy and citizenship means presenting Competencybased, Democratic \& Humanistic textbooks. Making textbooks a source of inspiration for student learning, making learning centered on students, encouraging student achievement, developing regional and national cultural values for students. In addition, it also supports students to behave as good citizens.

The material aspect of the VII grade Civics Education textbook based on cultural literacy and citizenship means presenting material with an emphasis on developing an understanding of students' culture and citizenship. This aspect is presented by taking into account the suitability of the material with life, the adequacy of the material for understanding students' regional and national cultures, the accuracy of the material with current learning needs, balance, and knowledge information delivered sequentially namely data, facts, concepts, and theories.

Finally, the presentation of material in the VII grade Civics Education textbooks based on cultural literacy and citizenship still includes cognitive, affective, and psychomotor elements, national cultural values, applications to become relevant citizens using a contextual approach. In addition to paying attention to these rights, the presentation of material in the Civics Education textbook for Class VII SMP based on cultural and civic literacy also needs to pay attention to the principles and procedures for presenting subject matter.

The presentation of the readability aspect of the VII grade Civics Education textbook based on cultural literacy and citizenship is by paying attention to the level of difficulty of a material for students to understand. In this case, it means that the readability aspect of the VII grade Civics Education textbooks based on cultural and civic literacy is how to present various information in an easy-to-understand language and way.

In other words, the aspect of readability in textbooks means having to pay attention to the use of language, systematic delivery of material, attractive appearance of the book, the inclusion of other supporting information, such as appropriate images, data graphs as additional information, using an inductive approach to stimulate students' reasoning and encourage the use of other learning resources.

\section{CONCLUSION}

After carrying out the entire process of research stages, it is known that the presentation of the Civics Education textbook for Class VII SMP based on cultural literacy and citizenship compiled by the researcher has three important things, namely;

1. Noting the presence of the material aspects of textbooks based on government regulations, namely the presentation of the material aspect, legibility, graphics, and language.

2. Pay attention to the presentation model of the textbook. After the research process is carried out, it is known that the model with an authentic learning approach will support more optimal learning outcomes.

3. Assignment form. Assignments made must be adapted to the purpose of presenting the material in the textbook.

\section{ACKNOWLEDGMENTS}

The author expresses gratitude to Allah SWT for the completion of this journal, hopefully, it will be a charity whose reward will continue to flow until the end. The authors would like to thank the Indonesian Education University, Bandung, Manado State University, Manado, and The Third Annual Civic Education Conference on "Civic Education in Pandemic Covid-19: Challenges and Responses" for their support.

\section{REFERENCES}

[1] AI Hasanah, "Implementation of the 2013 curriculum in the learning process at MIN Pandansari Ngunut Tulungagung", Thesis, Tarbiyah faculty and teacher education, MI teacher education, Tulungagung State Islamic Institute, East Java, 2017.

[2] A. Schleicher, "PISA 2018 Insights and Interpretations", 2018.

[3] T. Harsiati, "characteristics of reading questions in the PISA program", Journal of Litera: vol, 17. No, 1. pp, 90-106. 2018. DOI: https://doi.org/10.2831/ltr.v17i1.19048

[4] A. Gita, "The Function of Online Media as a Media for Cultural Literacy for the Young Generation", Journal of The Messenger, Vol. 5, no. 1, pp. 16-30, 2013.

DOI: http://dx.doi.org/10.26623/themessenger.v5i1.218 
[5] Y. Hermawati, YA Apriliyani, "cultural literacy: comprehending Balinese woman locality in the short story collection of sagra", Journal of Grammar and Literature: Vol, 15, no. 2, pp. 93-103, 2020. DOI: https://doi.org/10.26499/loa.v15i2.2339

[6] K. Suryadi, "Innovation of Values and Communication Functions of Political Parties for Strengthening Civic Literacy". Script of Speech on the Inauguration of the Position of Professor of Political Communication Science at the Faculty of Social Science Education, 2010.

[7] Hadiansyah, et al., "Supporting Literacy Material Culture and Citizenship". Jakarta: Ministry of Education and Culture, 2017, p. 1-29.

[8] A.A. Wahab, Sapriya, "The Theory and Foundation of Citizenship Education". Bandung: CV Alfabeta, 2011.

[9] A. Idris, "Developing learning strategies and HOTS assessment in Civics subjects", Article. Downloaded on: March 8, 2020, from https://www.kompasiana.com/idrisapandi/5d395b7 e097f3624de278a62/mengembang-strategipembelajaran-dan-penilaian-hots-pada-matapelajar-ppkn?page=all.

[10] Tarigan, Tarigan, "Review of Indonesian Textbooks". Bandung: Space, 2009.

[11] P. Agustina, (2015), "Development of Pedagogical Content Knowledge (PCK) for Biology Teacher Candidates at Muhammadiyah University of Surakarta through Learning Simulations", Journal of Science Research and Learning, Vol, 1, no. 1, p. 115, 2015.2 DOI: http://dx.doi.org/10.30870/jppi.v1i1.323

[12] M. Horsley, R. Walker, "Reforming Homework: Practices, learning, and policy", South Yarra: Palgrave Macmillan, 2013.

[13] D. Lambert, D. Balderstone, "Learning to Teach Geography in the Secondary Schools", London: Routledge-Falmer, 2012.

[14] M.M. Hamdi, "Scope Sequence Curriculum", Journal of Islamic Education Management, Vol. 2, No. 1, pp. 12-22, 2018. https://ejournal.staidakrempyang.ac.id/index.php/intizam/article/view/43

[15] A. Abdulkarim, "Analysis of Civics Textbooks and Its Implications in the Development of Teaching Materials That Can Empower Students' Thinking Skills". Dissertation, unpublished. Bandung: Indonesian University of Education, 2005.

[16] A. Sanusi, "Several Dimensions of Education Quality", Bandung: FPS IKIP Bandung, 1990.
[17] D.P Tampubolon, "Reading Ability: Effective and Efficient Reading Techniques". Bandung: ANGKASA, 2008.

[18] T. Oakland, HB Lane, "Language, Reading, and Readability Formulas: Implications for Developing and Adapting Tests", International Journal of Testing, Vol, 4, no. 3, pp. 239-252. 2009. https://doi.org/10.1207/s15327574ijt0403_3

[19] Y. Rusyana, "Language and Literature in Education gamitan", Bandung, CV. Diponegiro 1984.

[20] J. Gilliland, "The Concept of Readability". London: Horder and Stoughton, Vol, 2, No, 2, pp., 24-29, $1968 . \quad$ https://doi.org/10.1111/j.1467 9345.1968.tb00749.x

[21] A. Mudzakir, "Quality Textbook Writing", https://www.academia.edu/6122171/PENULISAN _BUKU_TEKS_YANG_BERKUALITAS_Mudza kir_AS

[22] Sugiyono, "Quantitative, Qualitative and R\&D Research Methods", Bandung: Alfabeta, 2010.

[23] R.M, Branch, "Instructional Design; the ADDIE Approach". New York: Springer, 2009. 